\begin{tabular}{|c}
$\begin{array}{c}\text { Ambiente \& Água - An Interdisciplinary Journal of Applied Science } \\
\text { ISSN 1980-993X - doi:10.4136/1980-993X } \\
\text { www.ambi-agua.net } \\
\text { E-mail: ambi-agua@agro.unitau.br }\end{array}$ \\
\hline
\end{tabular}

\title{
Chemical and ecotoxicological assessments of water samples before and after being processed by a Water Treatment Plant
}

\author{
doi: 10.4136/ambi-agua.1292
}

Received: 28 Jan. 2014; Accepted: 08 Mar. 2014

\author{
Regina Teresa Rosim Monteiro ${ }^{1 *}$; Gabriela H. Silva ${ }^{1}$; Tamara G. Messias ${ }^{1}$; \\ Sonia C. N. Queiroz ${ }^{2}$; Marcia Regina Assalin ${ }^{2}$; Debora Renata Cassoli \\ Carlos Henrique Rocha Alves ${ }^{1}$; Antonio Carlos Ferreira ${ }^{3}$; Christian Blaise ${ }^{4}$ \\ ${ }^{1}$ Universidade de São Paulo (USP) - Piracicaba, SP, Brasil \\ Centro de Energia Nuclear na Agricultura \\ ${ }^{2}$ Empresa Brasileira de Pesquisa Agropecuária (Embrapa) - Jaguariúna, SP, Brasil \\ Embrapa Meio Ambiente \\ ${ }^{3}$ Serviço Municipal de Água e Esgoto (SEMAE), Piracicaba, SP, Brasil \\ ${ }^{4}$ Centre Saint-Laurent - Montreal, Quebec, Canada \\ Environment Canada \\ *Autor correspondente: e-mail: monteiro@ @ena.usp.br, \\ gaby_helena@hotmail.com, tamessias@gmail.com, sonia.queiroz@embrapa.br, \\ marcia.assalin@embrapa.br,debora.cassoli@embrapa.br, chra9@hotmail.com, \\ acferreira@semaepiracicaba.sp.gov.br, christian.blaise@ec.gc.ca
}

\begin{abstract}
Physicochemical and ecotoxicological measurements were employed to appraise the water quality of the Corumbataí River raw water (RW) intake, and that of its filtered (FW) and treated (TW) waters, processed by the Water Treatment Plant (WTP) of Piracicaba (SP, Brazil) during 2010. Some herbicides: ametrine, atrazine, simazine and tebuthiuron, were measured, with levels ranging from 0.01 to $10.3 \mu \mathrm{g} \mathrm{L}^{-1}$. These were lower than those required to produce ecotoxicological effects to aquatic life based on published literature. Similarly, trihalomethanes, such as chloroform and bromodichloromethane produced as a result of the WTP process were also shown to be present in concentrations that would neither harm environmental nor human health. Elevated free chlorine concentrations found in FW and TW were credibly responsible for toxicity effects observed in algae and daphnids. (Pseudokirchneriella subcapitata and Daphnia magna). In contrast, results of toxicity testing conducted with Hydra attenuata suggested that this organism is resistant to free chorine and could be used for drinking water evaluations. Coupling bioassays with chemical analyses proved valuable to uncover putative cause-effect relationships existing between physical, chemical and toxic results, as well as in optimizing data interpretation of water quality.
\end{abstract}

Keywords: herbicides residues, trihalomethanes, drinking water.

\section{Avaliações químicas e ecotoxicológicas em amostras de água antes e após serem processadas por uma Estação de Tratamento}

\section{RESUMO}

Avaliações físico-químicas e ecotoxicológicas foram utilizadas para avaliar a qualidade de amostras da água do rio Corumbataí, água bruta $(\mathrm{RW})$, filtrada $(\mathrm{FW})$ e tratada $(\mathrm{TW})$, 
processadas pela Estação de Tratamento de Água (ETA) de Piracicaba (SP, Brasil), em 2010. Alguns resíduos de herbicidas, tais como: ametrina, atrazina, simazina e tebutiuron, foram medidos encontrando níveis entre $0,01-10,3 \mu \mathrm{g} \mathrm{L}^{-1}$ sendo esses menores do que os necessários para produzir efeitos ecotóxicos à vida aquática, com base na literatura publicada. Da mesma forma, trihalometanos, tais como: clorofórmio e bromodiclorometano produzido como resultados do processo da ETA foram também encontrados em concentrações que não prejudicam a saúde ambiental ou humana. Concentrações de cloro livre elevadas foram encontradas nas amostras de água FW e TW e foram os prováveis responsáveis pelos efeitos de toxicidade observados em algas e dáfnias (Pseudokirchneriella subcapitata, Daphnia magna). Por outro lado, resultados dos testes de toxicidade realizados com Hydra attenuata mostraram que este organismo é resistente a água clorado sendo um organismo potencial a ser utilizado para avaliações ecotoxicológicas em águas tratadas. Testes de toxicidade simultâneos com análises químicas revelaram úteis para descobrir relações de causa-efeito existentes entre supostos resultados tóxicos, físicos e químicos e, assim como na melhora de interpretação de dados de qualidade da água.

Palavras-chave: resíduos de herbicidas, trihalometanos, água tratada.

\section{INTRODUCTION}

Water quality is a planetary issue circumscribing both environmental and human health considerations. Adequate physicochemical characteristics of waters coupled with absence of harmful chemical (e.g., metal and organic contaminants) and biological agents (e.g., pathogenic bacteria and parasites) will ensure their good ecological and sanitary status.

Indeed, the type or degree of water treatment for domestic use is strongly dependent on the quality of its source. Classic treatments initially call for gas chlorination of raw water that is efficient in oxidizing harmful substances, followed by calcium addition for $\mathrm{pH}$ adjustment and $\mathrm{Al}(\mathrm{OH})_{3}$ and/or $\mathrm{Fe}(\mathrm{OH})_{3}$ to coagulate colloidal impurities. Water treated in this fashion next goes to lagoons for flocculation, then decantation and filtration. Final water quality is guaranteed with chlorine, fluorine and lime treatment. While chlorine is intended to inactivate or destroy disease-causing organisms that may still be present in water after treatment, lime serves to neutralize excess acidity in order to offset pipe corrosion for water distribution. Addition of fluorine offers protection against tooth decay, as recommended by the World Health Organization (WHO, 2006).

However, water treatment is a double-edged sword that can have both positive and negative consequences. Public health has greatly benefited over time from treatment processes owing to reduction of microbial epidemics in countries applying water sanitation programs (Farland and Gibb, 1993). On the other hand, chlorine addition to water enables reactions with available organic compounds, such as proteins, to form toxic byproducts. The best known products are trihalomethanes (THMs), such as chloroform or trichloromethane $\left(\mathrm{CHCl}_{3}\right)$, bromodichloromethane $\left(\mathrm{CHBrCl}_{2}\right)$ and dibromochloromethane $\left(\mathrm{CHBr}_{2} \mathrm{Cl}\right)$, among others (Paschoalato et al., 2008).

There is unquestionably a risk associated with chemicals used in water treatment. Epidemiological studies have shown positive associations between presence of THMs in drinking water and bladder cancer, and also with recreational activities in water, such as bathing, that lead to greater exposure by inhalation and dermal absorption, all of which incur higher risks than that posed by preparation and consumption of food (Villanueva et al., 2007). A connection between the presence of THMs in tap water supplied to the metropolitan region of São Paulo and aspects of low weight in newborns has been found, as well as congenital malformation and prematurity (Santos and Gouvea, 2011). TMHs are clearly a concern for public health in Brazil, and a maximum allowed concentration of $0.1 \mathrm{mg} \mathrm{L}^{-1}$ has been set for 
drinking water (Brasil, 2011). Because THMs are just some of the byproducts that can be formed by chlorination, their presence can signal that of other potentially hazardous chemicals (Silva et al., 2013). Therefore, control of THMs in water supplies could help reduce the levels of other compounds originating from chlorination (WHO, 1966).

Pesticides comprise another class of pollutants widely found in surface and underground water bodies worldwide, due to their widespread use in agricultural and urban areas (Schäfer et al., 2011). The presence of herbicides, in particular, has been observed in the Corumbataí River (Armas et al., 2005; Monteiro et al., 2008), the aqueous source processed by the water treatment plant (WTP) of this investigation.

Our study sought to assess the quality of water processed by the Water Treatment Plant (WTP) of Piracicaba (SP, Brazil), the source of which is the Corumbataí River. After treatment, drinking water is distributed to populations living in the municipality of Piracicaba (SP, Brazil). To optimize the scope of our investigation, we made use of a combined chemical-biological strategy incorporating physicochemical $\left(\mathrm{O}_{2}, \mathrm{pH}\right.$, conductivity, $\mathrm{T}{ }^{\circ} \mathrm{C}$, free chlorine) and chemical analysis (THMs, herbicides), as well as effects measurements by selected ecotoxicological tests representative of diverse aquatic life (algae and microinvertebrates). Within this approach, a secondary objective sought to appreciate the usefulness of bioassays in complementing chemical analysis in interpreting water quality.

\section{MATERIAL AND METHODS}

\subsection{Sampling}

Water samples were collected at different sites (Figure 1) in March, May, July, October and December of 2010. Samples were collected at sampling stations with a grab sampler and placed in three different $1 \mathrm{~L}$ polypropylene bottles $(1 \mathrm{~L}$ for physicochemical analysis, $1 \mathrm{~L}$ for contaminant analysis and $1 \mathrm{~L}$ for bioassays) and kept at $4^{\circ} \mathrm{C}$ in a cooler containing icepacks for immediate transport to the laboratory. Upon arrival, samples for contaminant analysis were frozen at $-18^{\circ} \mathrm{C}$.

Production of drinking water by the WTP from treated Corumbataí River water is illustrated in Figure 1. Briefly, raw river water intake is first subjected to gas chlorination to promote oxidation of potentially hazardous compounds, and afterwards receives calcium $\left(\mathrm{Ca}(\mathrm{OH})_{2}\right)$ addition for $\mathrm{pH}$ adjustment and $\mathrm{PAC}-\mathrm{Al}(\mathrm{OH})_{3}$ to coagulate colloidal impurities. Flocculation, decantation and sand/charcoal filtration of water then occur in lagoons. Lastly, $\mathrm{pH}$-neutralizing lime addition to prevent pipe corrosion during water distribution, as well as chlorination and fluorination to ensure and enhance water quality, essentially terminate the WTP drinking water production process.

\subsection{Rainfall data collection}

The cumulative rainfall of each month and cumulative five days before collecting water samples (Table 1) were provided by the pluviometric database of the automated Meteorological Station of Piracicaba (USP, 2011).

\subsection{Chemical analysis}

\subsubsection{Physicochemical determinations}

Temperature, $\mathrm{pH}$, conductivity and dissolved oxygen were measured using the equipment's Digimed DM2 ${ }^{\circledR}$ and $\mathrm{CD} 21^{\circledR}$ (Digimed, São Paulo, SP, Brasil), according to manufacturer's instructions. Free chlorine was measured by titration (APHA et al., 2005). 


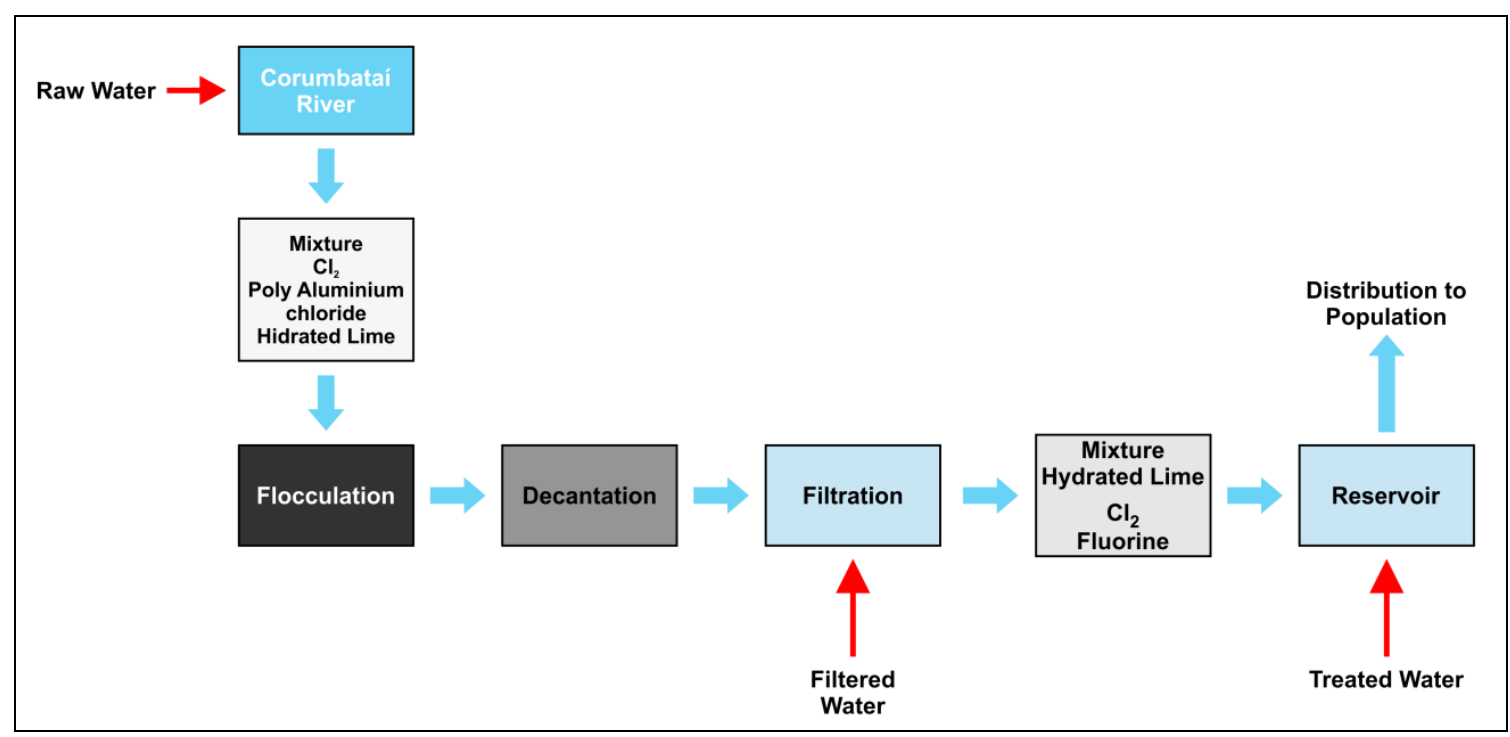

Figura 1. Water Treatment Plant (WTP) process and sampling stations.

Table 1. Cumulative rainfall data of the month and five days before collecting water.

\begin{tabular}{c|cc}
\hline Sampling period (2010) & $\begin{array}{c}\text { Rainfall month } \\
(\mathrm{mm})\end{array}$ & $\begin{array}{c}\text { Rainfall 5 days } \\
(\mathrm{mm})\end{array}$ \\
\hline March & 98.4 & 0.0 \\
May & 24.4 & 4.9 \\
July & 62.1 & 0.0 \\
October & 87.4 & 28.2 \\
December & 243.8 & 40.2 \\
\hline
\end{tabular}

\subsubsection{Trihalomethanes}

Chloroform, bromodichloromethane, dibromochloromethane and bromoform, 2000 $\mu \mathrm{g} \mathrm{mL}^{-1}$, were purchased from Supelco, (Bellefonte, PA, USA). The method was adapted from Serrano and Gallego (2007) and Cuela et al. (2006). A Quattro Micro Waters Gas Chromatography $^{\circledR}$ (Waters, Milford, MA, USA) coupled to mass spectrometer (CG-MS/MS) apparatus was used; which included a CTC Analytics autosampler (CombiPal). The capillary column used was DB-5 MS $30 \times 0.25 \mathrm{~mm} \mathrm{X} 0.25 \mu \mathrm{m}$ with a constant flow of $1.0 \mathrm{~mL} \mathrm{~min}{ }^{-1}$. Chromatographic conditions were as follows: oven temperature $31^{\circ} \mathrm{C}(1 \mathrm{~min})$, increased $1^{\circ} \mathrm{C} \mathrm{m^{-1 }}$ until $33^{\circ} \mathrm{C}(2 \mathrm{~min})$ and up to $200^{\circ} \mathrm{C}$ at $100^{\circ} \mathrm{C} \min ^{-1}(3 \mathrm{~min})$; inlet mode, splitless operation with and temperature at $200^{\circ} \mathrm{C}$. Electron ionization $(70 \mathrm{eV})$ was applied in the SIR mode, the following ions were used: $\mathrm{m} / \mathrm{z}$ 47, 83, 85 for Chloroform; m/z. 83, 85, 129 for dichlorobromomethane; $\mathrm{m} / \mathrm{z} 83,85,129$ for dibromochloromethane; and m/z 171, 173, 175 for bromoform. The transferline temperature was $250^{\circ} \mathrm{C}$ and source temperature at $150^{\circ} \mathrm{C}$. Headspace (HS) method: for the HS procedure, $12 \mathrm{~mL}$ of each water sample, mixed with $3 \mathrm{~g}$ of $\mathrm{KCl}$, were added to glass tubes. The tubes were sealed with rubber caps, the content mixed, and placed in an oven at $80^{\circ} \mathrm{C}$ for $20 \mathrm{~min}$ to permit the $\mathrm{HS}$ to reach equilibrium. A gas aliquot of $1 \mathrm{~mL}$ was withdrawn through the rubber cap with a gas-tight syringe and injected into the gas chromatograph. The syringe was maintained at $90^{\circ} \mathrm{C}$ in order to prevent internal condensation on the walls. The linearity was in the range $0.05-1.50 \mu \mathrm{g} \mathrm{mL}^{-1}$.

\subsubsection{Herbicides}

The choice for the water sample from October was due after long heavy rain following a prolonged drought. A $250 \mathrm{~mL}$ volume of water sample was percolated through the SPE 
cartridges (Oasis HLB, Waters) under vacuum at a flow-rate of $5 \mathrm{~mL} \mathrm{~min}^{-1}$. Before sample application, the SPE cartridges were conditioned with $1 \mathrm{~mL}$ of methanol and equilibrated with $1 \mathrm{~mL}$ of water $\mathrm{pH} 2.0$. After the sample had passed through the cartridge by vacuum, the cartridge was washed with methanol:water $(5: 95, \mathrm{v} / \mathrm{v})$ and dried under vacuum for $5 \mathrm{~min}$. The analytes were then eluted with $2 \mathrm{~mL}$ of methanol and submitted to the LC-MS/MS analysis.

The chromatographic separations were carried out on a Varian $1200 \mathrm{~L}$ triple quadrupole MS/MS using a Polaris $3 \mathrm{C} 18 \mathrm{~A}$ column $(150 \mathrm{~mm}$ X $2.0 \mathrm{~mm}$ i.d., $5 \mu \mathrm{m}$ particle size). The mobile phase consisted of deionized water with ammonium acetate $10 \mathrm{mM} \mathrm{L}^{-1}$ : Methanol 25:75 (v/v). The mobile phases were filtered daily using $0.22 \mu \mathrm{m}$ filters. The flow rate was $0.20 \mathrm{~mL} \mathrm{~min}^{-1}$ and the total run time of $18 \mathrm{~min}$. The mass spectrometer with an electrospray ionization source working in positive and negative ionization mode was used. The optimal for ionization of the analytes were source temperature, $50^{\circ} \mathrm{C}$; pressure and temperature of desolvation gas $\left(\mathrm{N}_{2}\right) 28$ psi and $280^{\circ} \mathrm{C}$, respectively. Argon was used as the collision gas. Acquisition was performed in multiple-reaction monitoring (MRM) mode. Electrospray ionization working parameters (ionization mode, precursor and product ions, cone voltage and collision energy) were optimized using infusion of individual standards solutions of the compounds $\left(1 \mu \mathrm{g} \mathrm{mL}^{-1}\right)$ at $20 \mu \mathrm{L} \mathrm{min}{ }^{-1}$. The MRM transitions monitored were Ametryn (228>186 and 228>96) Atrazine (216>174 and 216>95.9) Simazine (202.0>124.0 and 202.0>95.9) Picloram (239.9>124.9 and $239.9>158.9)$ and Tebuthiuron $(228.0>172.0$ and $228.0>115.9)$. The validation procedure was conducted to determine, selectivity, linearity, recovery of the pesticides, limit of quantification (LOQ), accuracy, and precision (repeatability and intermediate precision). The response of detector was linear for all herbicides studied the range $0.005-0.050 \mu \mathrm{g} \mathrm{mL}^{-1}$ with correlations coefficients $>0.99$. The quantification limit of this method was $0.008 \mu \mathrm{g} \mathrm{L}^{-1}$ for Ametryn, Atrazine and Tebuthiuron. For others herbicides the quantification limit was $0.08 \mu \mathrm{g} \mathrm{L}^{-1}$. The validated method showed good recuperation for all pesticides between $70-120 \%$.

\subsection{Toxicity tests and statistical analyses.}

Four well-standardized bioassays representing three trophic levels were employed to assess the toxic potential of all water samples. Test organisms comprised Hydra attenuatea (Blaise and Kusui, 1997), Daphnia magna (Environment Canada, 1996) and Pseudokirchneriella subcaptata (Blaise et al., 2000), as, secondary and primary consumer and producer, respectively. The methodological procedures are described in Santos et al. (2007).

Correlation analysis was also performed on physicochemical data parameters, as well as on toxicity test endpoint results, and combinations thereof, using the Pearson-moment method to seek out trends among the various measurements compared. All statistical tests were performed using the Statistic software package (version 5.5). Based on results obtained, Redundancy Analysis (RDA) correlations based on Canoco software, as described by Hair et al. (1995), were also conducted on toxicity responses of algae and hydra to trihalomethanes and herbicides concentrations for the October 2010 data.

\section{RESULTS AND DISCUSSION}

\subsection{Physicochemical data}

The physicochemical characteristics of water intake from the Corumbataí River (RW samples) and its treatment by the WTP process (FW and TW samples) are reported in Table 2. Overall, RW sample parameters suggest that water taken up from this river appears adequate to undergo treatment for drinking water purposes. Indeed, dissolved oxygen (D.O.) levels display a normal range of variation from March to October (6.7 to $9.3 \mathrm{mg} \mathrm{L}^{-1}$ ). Only in December is a low value of $3.9 \mathrm{mg} \mathrm{L}^{-1}$ of dissolved oxygen observed for RW. This can likely 
be explained by substantially higher rainfall in December (see Table 1) that will increase organic loading to the river with subsequent trigger of increased microbial activity and oxygen consumption. Correlation analysis between rainfall (Table 1) and D.O. data (Table 2) tend to confirm this hypothesis as a significant negative relationship was observed between these two parameters $(\mathrm{R}=-0.93 ; p<0.05)$. Corumbataí River $\mathrm{RW}$ conductivity is also influenced by rainfall $(\mathrm{R}=-0.95 ; p<0.05)$, as the latter dilutes the former when precipitation increases [e.g., substantial rainfall in December 2010 of $243.8 \mathrm{~mm}$ (Table 1) decreases conductivity to a low of $130.8 \mu \mathrm{E} \mathrm{cm}$ (Table 2)]. In contrast to RW, FW as well as TW of the Corumbataí River demonstrate slight increase in $\mathrm{pH}$ and conductivity, as well as the presence of free chlorine (highest levels observed in TW), owing to WTP processes. The importance of each physical and chemical parameter measured is parsed and presented by Araújo and Oliveira (2013).

Table 2. Physicochemical characteristics of water samples from March to December 2010.

\begin{tabular}{l|cccccc}
\hline \multirow{3}{*}{ Period (2010) } & Sample type & $\begin{array}{c}\text { Dissolved } \\
\text { oxygen } \\
\left(\mathrm{mg} \mathrm{L}^{-1}\right)\end{array}$ & pH & $\begin{array}{c}\text { Conductivity } \\
\left(\mu \mathrm{S} \mathrm{cm}^{-1}\right)\end{array}$ & $\begin{array}{c}\text { Temperature } \\
\left({ }^{\circ} \mathrm{C}\right)\end{array}$ & $\begin{array}{c}\text { Free } \\
\text { Chlorine } \\
\left(\mathrm{mg} \mathrm{L}^{-1}\right)\end{array}$ \\
\hline \multirow{3}{*}{ March } & RW & 6.72 & 7.15 & 144.7 & 22.7 & 0.00 \\
& FW & 7.13 & 7.40 & 181.7 & 22.8 & 1.75 \\
& TW & 6.77 & 8.53 & 255.0 & 22.5 & 2.50 \\
\hline \multirow{3}{*}{ May } & RW & 8.14 & 6.70 & 165.0 & 22.3 & 0.00 \\
& FW & 7.24 & 7.96 & 215 & 22.3 & 0.35 \\
& TW & 7.32 & 8.20 & 231 & 22.5 & 2.50 \\
\hline \multirow{3}{*}{ October } & RW & 9.26 & 6.86 & 151.3 & 24.5 & 0.00 \\
& FW & 9.98 & 7.12 & 166.5 & 24.1 & 1.10 \\
& TW & 10.21 & 8.23 & 194.0 & 24.7 & 2.80 \\
\hline \multirow{3}{*}{ December } & RW & 7.43 & 7.30 & 149.3 & 23.4 & 0.00 \\
& FW & 7.78 & 7.90 & 211.0 & 23.6 & 0.34 \\
& TW & 8.12 & 8.34 & 223.8 & 24.7 & 2.10 \\
\hline & FW & 3.90 & 5.80 & 130.8 & 24.9 & 0.00 \\
& FW & 5.17 & 7.50 & 199.7 & 25.1 & 0.20 \\
\hline
\end{tabular}

Abbreviations: raw water (RW), filtered water (FW) and treated water (TW).

\subsection{Trihalomethanes and herbicide data}

Chemical analysis of some trihalomethanes (THMs) commonly formed during drinking water treatments (Paschoalato et al., 2008), and of herbicides whose presence has already been reported for the Corumbataí River (Armas et al., 2005; Monteiro et al., 2008), was undertaken following the October 2010 sampling of RW, FW and TW (Table 3). In the

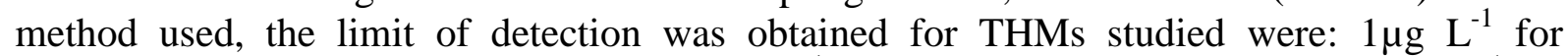
chloroform and dichlorobromomethane; $2 \mu \mathrm{g} \mathrm{L}^{-1}$ for dibromochloromethane and $5 \mu \mathrm{g} \mathrm{L}^{-1}$ for bromoform. At a signal/noise of 10/1 the limit of quantification was $5 \mu \mathrm{g} \mathrm{L}^{-1}$ for chloroform, dichlorobromomethane, dibromochloromethane and $25 \mu \mathrm{g} \mathrm{L}^{-1}$ for bromoform. While THMs 
were absent in RW, chloroform and bromodichloromethane were observed in both FW and TW, likely formed as a result of the WTP process. Their concentrations in TW destined for human consumption are, however, below the maximum acceptable concentration of $0.1 \mathrm{mg} \mathrm{L}^{1}$ set for drinking water in Brazil (Brasil, 2011).

Of the five herbicides analyzed following water sample collection in October 2010, only atrazine and simazina were found in RW, FW and/or TW samples. Ametryn was found in the RW sample. The results are shown in Table 3. Even though all samples were taken on the same day in October, FW and TW samples are representative of water that has already been in the WTP process for two days and they are therefore two days older than RW samples. This offers an explanation for the fluctuations in herbicide concentrations observed between RW and FW/TW samples. The herbicides atrazine and simazine were present in concentrations that surpass those considered acceptable for human consumption of $2 \mu \mathrm{g} \mathrm{L}^{-1}$ according to Brazilian regulations (Brazil, 2011). Furthermore, it is known that atrazine is not removed by WTPs (Benotti et al., 2009; Quintana et al., 2001). The potential ecotoxic effects of THM and herbicide concentrations found in RW, FW and TW are discussed along with the bioanalytical data presented below.

Table 3. Trihalomethane and herbicide residues $\left(\mu \mathrm{g} \mathrm{L}{ }^{-1}\right)$ in water samples of the Corumbataí River collected in October 2010 at the WTP.

\begin{tabular}{c|ccc}
\hline Trihalomethanes & $\mathrm{RW}$ & $\mathrm{FW}$ & $\mathrm{TW}$ \\
\hline Chloroform & $<\mathrm{LD}^{\mathrm{a}}$ & 87.4 & 26.9 \\
Bromodichloromethane & $<\mathrm{LD}^{\mathrm{a}}$ & $<\mathrm{LOQ}$ & $<\mathrm{LOQ}$ \\
Dibromochloromethane & $<\mathrm{LD}^{\mathrm{b}}$ & $<\mathrm{LD}^{\mathrm{b}}$ & $<\mathrm{LD}^{\mathrm{b}}$ \\
Bromoform & $<\mathrm{LD}^{\mathrm{c}}$ & $<\mathrm{LD}^{\mathrm{c}}$ & $<\mathrm{LD}^{\mathrm{c}}$ \\
\hline Herbicides & & & \\
\hline Ametrine & 0.29 & $<\mathrm{LOQ}^{\mathrm{d}}$ & $<\mathrm{LOQ}^{\mathrm{d}}$ \\
Atrazine & 8.21 & 10.31 & 7.24 \\
Simazine & 3.04 & 2.49 & 1.36 \\
Picloran & $<\mathrm{LOQ}^{\mathrm{d}}$ & $<\mathrm{LOQ}^{\mathrm{d}}$ & $<\mathrm{LOQ}^{\mathrm{d}}$ \\
Tebuthiuron & 0.01 & 0.01 & $<\mathrm{LOQ}^{\mathrm{d}}$ \\
\hline
\end{tabular}

Abbreviations: RW is raw water, FW is filtered water and TW is treated water.

LD: limit of detection ${ }^{\mathrm{a}}<1 \mu \mathrm{g} \mathrm{L}^{-1}$

LD: limit of detection ${ }^{b}<2 \mu \mathrm{g} \mathrm{L}^{-1}$

LD: limit of detection ${ }^{\mathrm{c}}<5 \mu \mathrm{g} \mathrm{L}^{-1}$

LOQ: limit of quantification ${ }^{\mathrm{d}}$

\subsection{Toxicity tests and data analysis}

The $H$. attenuata cnidarian bioassay failed to demonstrate toxicity in nearly all of the FW and TW samples or in RW samples with two exceptions: RW and FW samples collected in December yielded $96 \mathrm{~h}$-EC50s $=80 \%$, indicative of marginal sub-lethal toxic effects produced by these samples (Table 4). Arkhipchuk et al. (2006) also reported that H. attenuata could be successfully used for toxicity assessment of treated waters destined for human consumption.

Toxicity results in RW, FW and TW determined for the chlorophyte P. subcapitata are reported in Table 4. For RW, with the exception of the May and December samples, where $72 \mathrm{~h}-\mathrm{IC} 50 \mathrm{~s}$ were respectively of 66.9 and $33.4 \%$, all other samples were devoid of toxic effects. Correlation analysis indicates a link between $\mathrm{pH}$ and algal toxicity $(\mathrm{R}=0.89$; $p<0.05$ ), suggesting that $\mathrm{pH}$ may have at least partially contributed to phytotoxicity test results. Indeed, algal toxicity is highest $(72 \mathrm{~h}-\mathrm{IC} 50=33.4 \%$ in December (Table 4$)$ when 
sample $\mathrm{pH}$ is lowest ( $\mathrm{pH}=5.8$ in December, Table 2). Algal bioassay results for FW and TW show that all samples were toxic (Table 4). IC50s for FW are negatively correlated with free chlorine $(\mathrm{R}=-0.87 ; p<0.05)$ corroborating higher toxicity responses (i.e., decreasing IC50 values) with increasing chlorine concentrations. This is not surprising, as primary producers such as microalgae suffer growth inhibition effects when reactive chlorine species surpass levels of $180 \mu \mathrm{g} \mathrm{L}^{-1}$ (Kott et al., 1966). TW samples were even more toxic than FW samples as all IC50s were $<12.5 \%$, the lowest concentration tested with this bioassay. The higher levels of free chlorine present in TW samples (Table 2) are, again, allegedly responsible for the observed algal toxicity. When sodium thiosulphate was added to FW and TW samples, algal toxicity was completely eliminated, confirming once again its link with free chlorine (Table 4).

In October 2010, THMs were analyzed and quantified in FW and TW (Table 3) ranging from about $3 \mu \mathrm{g} \mathrm{L}^{-1}$ (bromodichloromethane, TW) to $87.4 \mu \mathrm{g} \mathrm{L}^{-1}$ (chloroform, FW). These levels are inferior to those required to elicit toxicity in algal species. Indeed, for the most susceptible algal species, reduced growth in blue-green and green algae exposed to THMs has been reported at concentrations of approximately $185 \mathrm{mg} \mathrm{L}^{-1}$ by Bringmann and Kühn (1978), thereby excluding THMs in having played a part in the phytotoxic effects observed in the present study. Similarly, the concentrations of herbicides measured in October 2010 in RW, FW and TW are low for causing algal toxicity (Table 3). For example, 96 h-IC50 bioassays performed with $S$. capricornutum (today called $P$. subcapitata) for atrazine yielded endpoint values of $128.2 \mu \mathrm{g} \mathrm{L}^{-1}$ and $130 \mu \mathrm{g} \mathrm{L}^{-1}$ (Gala and Giesy, 1990; Hoberg, 1991). Using the same algal species, a $96 \mathrm{~h}$-IC50 of $1240 \mu \mathrm{g} \mathrm{L}{ }^{-1}$ was reported for simazine (Fairchild et al., 1997). Again, toxicity toward $S$. capricornutum exposed to tebuthiuron (Blaise and Harwood, 1991) cited a $96 \mathrm{~h}$-IC50 $=0.1 \mathrm{mg} \mathrm{L}^{-1}$, an endpoint value 10,000 times higher than the concentration found in RW and FW for this herbicide (Table 3). The algal toxicity observed in May and December for RW, probably are due to the presence of herbicides. Armas et al. (2005) and Monteiro et al. (2008) found residues of ametrine, glyphosate, 2,4-D, diuron, methribuzin, sulfentrazone, throughout the year on samples of Corumbataí River water.

Ecotoxicity data determined using water fleas are reported in Table 4. D. magna bioassays performed on RW samples were all exempt of toxic effects (LC50s > 100\%), supporting all other bioassay results that Corumbataí River water quality is free from toxicity at the point where it is taken up for the WTP drinking water process. Daphnids are known for their marked sensitivity to chlorinated water. For example, Fisher et al. (1999) reported a $48 \mathrm{~h}$-LC50 of $32 \mu \mathrm{g} \mathrm{L}^{-1}$ for the water flea, D. magna, exposed to reactive chlorine species. Hence, this likely explains their toxic responses in both chlorine-laden FW and TW samples, although no significant correlation was observed between free chlorine and LC50s in these waters $(\mathrm{R}=-0.41 ; p=0.49$ in $\mathrm{FW}$ and $\mathrm{R}=-0.040 ; p=0.94$ in $\mathrm{TW})$. While production of THMs during WTP process in FW and TW could also be claimed to have contributed to the toxicity of these micro-invertebrates, this is not supported by the scientific literature (LeBlanc, 1980; Abernethy et al., 1986), which situates the range of THM toxicity to D. magna between 29 to $78.9 \mathrm{mg} \mathrm{L}^{-1}$ for $48 \mathrm{~h}-\mathrm{LC} 50 \mathrm{~s}$, endpoint values which are superior to THM concentrations quantified in FW and TW in October 2010 (Table 4).

The herbicide levels reported in October 2010 for RW, FW and TW were also low to elicit toxicity toward cladocerans (Table 3 ). Atrazine toxicity to D. magna, for example, was reported to be in the range of $49 \mathrm{mg} \mathrm{L}^{-1}$ (Putt, 1991). For simazine, $48 \mathrm{~h}$-LC50s for D. magna were scored at 1 and $3.5 \mathrm{mg} \mathrm{L}^{-1}$ by Sanders (1970) and Marchini et al. (1988), respectively. For tebuthiuron, D. magna toxicity was estimated to be $100 \mathrm{mg} \mathrm{L}^{-1}$ (Meyerhoff et al., 1985). Interactions between free chlorine, THMs and/or herbicides found in FW and TW in October 2010 cannot, however, be excluded as a possible explanation for at least some of the observed toxicity toward daphnids. Lastly, sodium thiosulphate addition $(0.18 \%)$ to FW and TW 
samples, as occurred with algae, completely eliminated daphnid toxicity (LC50 > 100\% v/v) in all samples (Table 4).

Table 4. Toxicity to P. subcapitata (IC50-96 h), D. magna (LC50-46 h) and H. attenuata (EC50-96 h) in water samples, of Corumbataí River collected from March to December, 2010 at WTP. Values are expressed in \% v/v.

\begin{tabular}{l|ccc|ccc|ccc}
\hline \multirow{2}{*}{$\begin{array}{c}\text { Sampling } \\
\text { Period }\end{array}$} & \multicolumn{3}{|c}{ P. subcapitata } & \multicolumn{3}{c|}{ D. magna } & \multicolumn{3}{c}{ H.attenuata } \\
\cline { 2 - 9 } & RW & FW $^{\mathbf{b}}$ & $\mathbf{T W}^{\mathbf{b}}$ & $\mathbf{R W}$ & $\mathbf{F W}^{\mathbf{b}}$ & $\mathbf{T W}^{\mathbf{b}}$ & $\mathbf{R W}$ & FW $^{\mathbf{b}}$ & $\mathbf{T W}^{\mathbf{b}}$ \\
\hline March & $>100$ & $<12.5^{\text {a }}$ & $<12.5$ & $>100$ & $<12.5$ & $<12.5$ & $>100$ & $>100$ & $>100$ \\
May & 66.9 & 26.0 & $<12.5$ & $>100$ & 55.3 & $<12.5$ & $>100$ & $>100$ & $>100$ \\
July & $>100$ & $<12.5$ & $<12.5$ & $>100$ & $>100$ & $<12.5$ & $>100$ & $>100$ & $>100$ \\
October & $>100$ & 19.7 & $<12.5$ & $>100$ & 35.4 & $<12.5$ & $>100$ & $>100$ & $>100$ \\
December & 33.4 & 36.2 & $<12.5$ & $>100$ & 95.3 & 15.6 & 89.0 & 80.2 & $>100$ \\
\hline
\end{tabular}

Abbreviations: raw water (RW), filtered water (FW) and treated water (TW). ${ }^{\mathrm{a}}$ Concentration of $12,5 \% \mathrm{v} / \mathrm{v}$, was the lowest tested. ${ }^{\mathrm{B}}$ Addition of $\mathrm{Na}$ thiosulphate $(0.18 \%)$ to water samples completely eliminated toxicity (LC50 or IC50 $>100 \% \mathrm{v} / \mathrm{v}$ ) in all samples.

\subsection{Redundancy analysis}

RDA performed on October 2010 data (Figure 2) confirms an association among trihalomethanes (chloroform and bromodichloromethane) and free chlorine, an unexpected relationship. This is due to the fact that THMs are formed as byproducts from organic and chlorine interactions in WTPs. Free chlorine, in particular, because of its long arrow line and opposite direction to lines of D. magna and P. subcapitata, is apparently linked to toxicity responses of these aquatic organisms (Figure 1). RDA also does not show any association between herbicides (atrazine and simazine) and toxicity to these same organisms, as previously suggested by Pearson-moment correlation analysis. However, long-term health effects for human consumers of drinking water cannot be excluded, as atrazine and simazine were found at levels exceeding Brazilian regulations for drinking water.

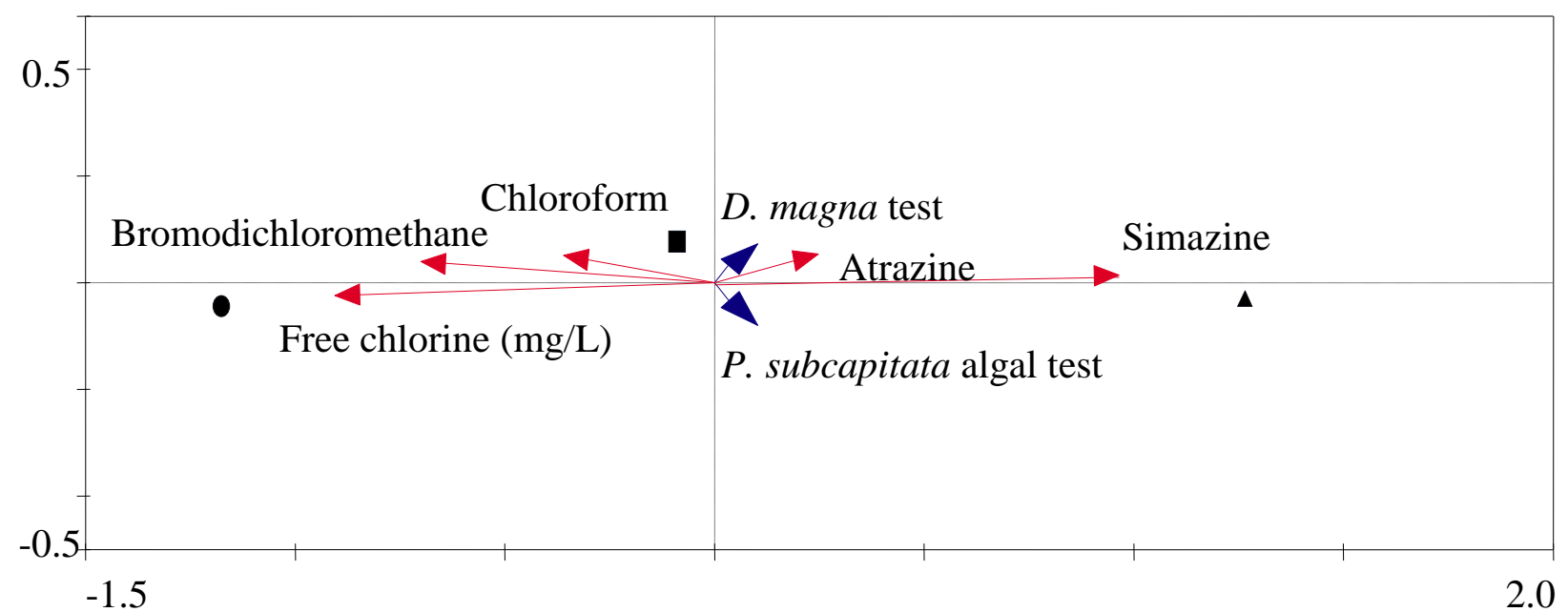

Figure 2. Redundancy analysis (RDA) exploring relationships with toxicity responses of algae $P$. subcapitata and D. magna versus trihalomethane and herbicide residue concentrations for the October 2010 data, present in RW ( $)$, FW (ם) and TW (•). 
Finally, it is worth mentioning that the Corumbataí River could possibly be influenced by other classes of chemical contaminants. Indeed, the presence of Bisphenol A and caffeine has been recently reported (Raimundo, 2011), and this may suggest that the Corumbataí River could likely be the recipient of a yet undetermined load of pharmaceutical residues. In fact, Raimundo (2011) investigated assessing the removal of 16 priority organic micro-pollutants by the WTP. Atrazine was found in sampled water during two sampling outings to the Corumbataí River in 2011. Atrazine levels ranged from 4.8 to $7.5 \mathrm{ng} \mathrm{L}^{-1}$ in Corumbataí River water (RW), while they ranged from 4.7 to $16.5 \mathrm{ng} \mathrm{L}^{-1}$ in WTP treated water, indicating the treatment did not eliminate atrazine residues. Again, Bisphenol A concentrations in raw water ranged between 5.7 to $27.3 \mathrm{ng} \mathrm{L}^{-1}$ and between $<0.5$ to $2.2 \mathrm{ng} \mathrm{L}^{-1}$ in drinking water. In comparison, an atrazine concentration of $9.3 \mu \mathrm{g} \mathrm{L} \mathrm{L}^{-1}$ was reported in a surveillance study of drinking water in the U.S.A. (Benotti et al., 2009). These recent findings guarantee future investigations to assess whether these classes of emerging substances could be hazardous to aquatic life and human health (Umbuzeiro, 2012).

\section{CONCLUSIONS}

This investigation demonstrated that coupling ecotoxicological tests, physical and chemical analysis proved valuable to monitor the water quality of the Corumbataí River, and that of its treated waters processed by the Water Treatment Plant (WTP) of Piracicaba, SP, Brazil. Global data amassed enabled us to optimize interpretation associated with the water quality of raw, filtered and treated samples, as well as to uncover some cause-effect relationships existing between physical, chemical and toxicity results.

\section{ACKNOWLEDGEMENTS}

We are grateful to CNPq for the financial support (474948/2009-9). Appreciation is extended to CNPq, CAPES and FAPESP for the research grants.

\section{REFERENCES}

ABERNETHY, S.; BOBRA, A. M.; SHIU, W. Y.; WELLS, P. G.; MACKAY, D. Acute lethal toxicity of hydrocarbons and chlorinated hydrocarbons to two planktonic crustaceans: The key role of organism-water partitioning. Aquatic Toxicology, v. 8, p. 163-174, 1986. http://dx.doi.org/10.1016/0166-445X(86)90062-7

AMERICAN PUBLIC HEALTH ASSOCIATION - APHA AMERICAN WATER WORKS ASSOCIATION - AWWA; WATER ENVIRONMENT FEDERATION - WEF. Standard methods for the examination of water and wastewater. 20 . ed. Washington, DC 2005.

ARAÚJO, M. C.; OLIVEIRA, M. B. M. Monitoramento da qualidade das águas de um riacho da Universidade. Revista Ambiente \& Água, v. 8, n.3 p. 247-257, 2013. http://dx.doi.org/10.4136/ambi-agua.1192

ARKHIPCHUK, V. V.; BLAISE, C.; MALINOVSKAYA, M. V. Use of Hydra for chronic toxicity assessment of waters intended for human consumption. Environmental Pollution, v. 142, p. 200-211, 2006. http://dx.doi.org/10.1016/j.envpol.2005.10.012 
ARMAS, E. D.; MONTEIRO, R. T. R.; AMÂNCIO, A. V.; CORREA, R. M. L.; GUERCIO, M. A. Uso de agrotóxicos em cana-de-açúcar na bacia do rio Corumbataí e o risco de poluição hídrica. Química Nova, v. 28, p. 975-982, 2005. http://dx.doi.org/10.1590/S0100-40422005000600008.

BENOTTI, M. J.; TRENHOLM, R. A.; VAN DER FORD, B. J.; HOLADY, J. C.; STANFORD, B. D.; SNYDER, S. A. Pharmaceuticals and endocrine disrupting compounds in U.S. drinking water. Environment Science Technology, v. 43, p. 597603, 2009. http://dx.doi.org/10.1021/es801845a.

BLAISE, C.; FORGET, G.; TROTTIER, S. Toxicity screening of aqueous samples using a cost-effective 72-h exposure Selenastrum capricornutum assay. Environmental Toxicology, v. 15, p. 352-359, 2000. http://dx.doi.org/10.1002/15227278(2000)15:4<352::AID-TOX12>3.0.CO;2-L

BLAISE, C.; HARWOOD, M. Contribution à l'évaluation écotoxicologique du Tébuthiuron - un herbicide de la classe des urées substituées. Revue des Sciences de l' Eau, v. 4, p. 121-134, 1991.

BLAISE, C.; KUSUI, T. Acute toxicity assessment of industrial effluents with a microplatebased Hydra attenuata assay. Environment Toxicology of Water Quality, v. 12, p. 5360, $1997 . \quad$ http://dx.doi.org/10.1002/(SICI)1098-2256(1997)12:1<53::AIDTOX8>3.0.CO;2-7

BRASIL. Ministério da Saúde. Portaria no 2.914/2011. Procedimentos de controle e de vigilância da qualidade da água para consumo humano e seu padrão de potabilidade. Diário Oficial da União, Seção 1, p. 39-46, 2011.

BRINGMANN, G.; KÜHN, R. Limiting values for the noxious effects of water pollutant material to blue algae (Microcystis aeruginosa) and green algae (Scenedesmus quadricauda) in the cell multiplication inhibition test. Vom Wasser, v. 50, p. 45-60, 1978.

CUELA, M.; COZAR, O.; RISTOIU, D. Methods validation for the determination of trihalomethanes in drinking water. Journal of Mass Spectrometry, v. 41, p. 15941597, 2006. http://dx.doi.org/10.1002/jms.1149

ENVIRONMENT CANADA. Biological test method: acute lethality test using Daphnia species, amended version. Ottawa, 1996. (EPS 1/RM/11).

FAIRCHILD, J. F.; RUESSLER, D. S.; HEVERLAND, P. S.; CARLSON, A. R. Comparative sensitivity of Selenastrum capricornutum and Lemna minor to sixteen herbicides. Archives of Environmental Contamination and Toxicology, v. 32, p 353-357, 1997. http://dx.doi.org/10.1007/s002449900196

FARLAND, W. H.; GIBB, H. J. U. S. Perspective on balancing chemical and microbial risks of disinfection. In: CRAU, G. (Ed.). Safety of Water Disinfection: balancing chemical and microbial risks. Washington, DC: ILSI Press, 1993. p. 3-10.

FISHER, D. J.; BURTON, D. T.; YONKOS, L. T.; TURLEY, S. D.; ZIEGLER G. P. The relative acute toxicity of continuous and intermittent exposures of chlorine and bromine to aquatic organisms in the presence and absence of ammonia. Water Research, v. 33, p. 760-768, 1999. http://dx.doi.org/10.1016/S0043-1354(98)00278-4 
GALA, W. R.; GIESY, J. P. Flow cytometric techniques to assess toxicity to algae. In: VAN DER SHALIE, W. H.; LANDIS, W. G. Aquatic toxicology and risk assessment: thirteenth volume. Philadelphia: ASTM, 1990. p. 237-246. (STP, 1096).

HAIR, J. F.; TAHAM, R. L.; BLACK, W. C. Multivariate data analysis. 4. ed. New Jersey: Prentice Hall, 1995.

HOBERG, J. R. Atrazine technical-toxicity to the freshwater green alga Selenastrum capricornutum. Duluth: USEPA, 1991. (MRID No. 420607-01).

KOTT, Y.; HERSHKOVITZ, G.; SHEMTOB, A.; SLESS, J. B. Algicidal effect of bromine and chlorine on Chlorella pyrenoidosa. Applied Microbiology, v. 14, p. 8-11, 1966.

LEBLANC, G. A. Acute toxicity of priority pollutants to water flea (Daphnia magna). Bulletin of Environmental Contamination and Toxicology, p. 24, p. 684-691, 1980. http://dx.doi.org/10.1007/BF01608174

MARCHINI, S.; PASSERINI, L.; CESAREO, D.; TOSATO M. L. Herbicidal triazines: Acute toxicity on Daphnia, fish, and plants and analysis of its relationships with structural factors. Ecotoxicology and Environmental Safety, v. 16, p. 148-157, 1988. http://dx.doi.org/10.1016/0147-6513(88)90029-2

MEYERHOFF, R. D.; GROTHE, D. W.; SAUTER, S.; DORULLA, G. K. Chronic toxicity of tebuthiuron to an alga (Selenastrum capricornutum) a cladoceran (Daphnia magna) and the fathead minnow (Pimephales promelas). Environmental Toxicology and Chemistry, p. 4, p. 695-701, 1985. http://dx.doi.org/10.1002/etc.5620040513

MONTEIRO, R. T. R.; ARMAS, E. D.; QUEIROZ, S. C. N. Lixiviação e contaminação das águas do rio Corumbataí por herbicidas. In: CONGRESSO BRASILEIRO DA CIÊNCIA DAS PLANTAS DANINHAS, 26.; CONGRESO DE LA ASOCIACIÓN LATINO-AMERICANA DE MALEZAS, 18., 2008, Ouro Preto. A ciência das plantas daninhas na sustentabilidade dos sistemas agrícolas. Ouro Preto: SBCPD, 2008. p. 181-192.

PASCHOALATO, C. F. P. R.; TRIMAILOVAS, M. R.; DI-BERNARDO, L. Formação de subprodutos orgânicos halogenados nas operações de pré-oxidação com cloro, ozônio e peroxônio e pós-cloração em água contendo substâncias húmicas. Engenharia Sanitária e Ambiental, v. 13, p. 313-322, 2008. http://dx.doi.org/10.1590/S141341522008000300011

PUTT, A. E. Acute toxicity to daphnids (Daphnia magna) under flow-through conditions. Duluth: USEPA, 1991. (MRID No. 420414-01).

QUINTANA, J.; MARTÍ, I.; VENTURA, F. Monitoring of pesticides in drinking and related waters in NE Spain with a multiresidue SPE-GC-MS method including an estimation of the uncertainty of the analytical results. Journal Chromatography A, v. 938, p. 3-13, 2001. http://dx.doi.org/10.1016/S0021-9673(01)01168-2

RAIMUNDO, C. C. M. Contaminantes emergentes em água tratada e seus mananciais: sazonalidade, remoção e atividade estrogênica. 2011. Tese (Doutorado em Ciências) - Instituto de Química, Universidade Estadual de Campinas, Campinas, 2011.

SANDERS, H. O. Toxicities of some herbicides to six species of freshwater crustaceans. Journal of Water Pollution Control Federation, v. 42, p. 1544-1550, 1970. http://www.jstor.org/stable/25036743 
SANTOS, M. A. P. F. Sensitivity of four test organisms (Chironomus xanthus, Daphnia magna, Hydra attenuata and Pseudokirchneriella subcapitata)to $\mathrm{NaCl}$ : an alternative reference toxicant. Journal of Brazilian Society of Ecotoxicology, v. 2, p. 229-236, 2007.

SANTOS, S. M.; GOUVEIA, N. Presença de trihalometanos na água e efeitos adversos na gravidez. Revista Brasileira de Epidemiologia, v. 14, p.106-119, 2011. http://dx.doi.org/10.1590/S1415-790X2011000100010

SCHÄFER, R. B.; VON DER OHE P. C.; KÜHNE, R.; SCHÜÜRMANN, R. G.; LIESS, M. Occurrence and toxicity of 331 organic pollutants in large rivers of north Germany over a decade (1994 a 2004). Environmental Science \& Technology, v. 45, p. 6167-6174, 2011. http://dx.doi.org/10.1021/es2013006

SERRANO, A.; GALLEGO, M. Rapid determination of total trihalomethanes index in drinking water. Journal Chromatography A, v. 1154, p. 26-33, 2007. http://dx.doi.org/10.1016/j.chroma.2007.03.101

SILVA, G. H.; MESSIAS, T. G.; LEME, D. M.; MONTEIRO, R. T. R. Mutagenicidade e genotoxicidade em águas superficiais e subterrâneas antes e após o tratamento da água. Holos Environment, v. 13, p. 64-73, 2013.

UMBUZEIRO, G. A. (Cord.) Guia de potabilidade para substâncias químicas. São Paulo: Abes, 2012. 144 p.

UNIVERSIDADE DE SÃO PAULO. Escola Superior de Agricultura Luiz de Queiroz. Estação Meteorológica da ESALQ/USP. Piracicaba, 2011. Available at: http://www.leb.esalq.usp.br/exceldados/DCE2011.TXT. Accessed at: June 132011.

VILLANUEVA, C. M.; CANTOR, K. P.; GRIMALT, J. O.; MALATS, N.; SILVERMAN, D.; TARDON, A. et al. Bladder cancer and exposure to water disinfection by-products trough ingestion, bathing, showering and swimming in pools. American Journal of Epidemiology, v. 165, p. 148-156, 2007. http://dx.doi.org/10.1093/aje/kwj364

WORLD HEALTH ORGANIZATION - WHO. Guidelines for drinking water quality. 2. ed. Geneva, 1996. v. 2, p. 849-872.

WORLD HEALTH ORGANIZATION - WHO. Guidelines for drinking water quality. First addendum to 3. ed. Recommendations. Geneva, 2006. v. 1. 